\title{
Association between Thyroid Hormone and Risk Factors of Metabolic Syndrome in Adult Men of Normal Thyroid Function
}

Kyung-A Shin

Department of Clinical Laboratory Science, Shinsung University, Dangjin 31801, Korea

\section{정상 갑상샘 기능을 보이는 성인 남성에서 갑상샘 호르몬과 대사증후군 위험요인과의 관계}

\author{
신경아
}

신성대학교 임상병리과

\begin{abstract}
Thyroid hormones are essential for cellular energy homeostasis and regulation by interacting with the sympathetic nervous system. This study was conducted to investigate the relationship between thyroid hormone and risk factors of metabolic syndrome for medical checkups of male patients. The study subjects were 12,250 males between 20 80 years old who visited the hospital for a health check-up at one General Hospital in Gyeonggi-do during the period of January 2011 to December 2013. According to the American Heart Association/National Heart, Lung, and Blood Institute (AHA/NHLBI), the metabolic syndrome criteria is defined as the presence of 3 or more risk factors. FT4 was lower in the metabolic syndrome group than in the normal group $(p<0.001)$. The level of FT4 decreased as the levels of abdominal obesity $(p=0.001)$, hypertriglyceridemia $(p<0.001)$, blood pressure $(p=0.005)$ and blood glucose $(p=0.005)$ increased. The TSH level increased hypertriglyceridemia $(p=0.047)$. FT4 had an influence on the waist circumference and triglyceride $(p<0.001) . \mathrm{HbA} 1 \mathrm{c}$, insulin, HOMA-IR, hs-CRP were higher in the lowest quartile than in the highest quartile $(p<0.001)$. FT4 had effects on the waist circumference and triglyceride, but TSH had no effect on metabolic syndrome risk factors. The metabolic syndrome was lower in the highest quartile of FT4 than in its lowest quartile.
\end{abstract}

Keywords: Thyroid hormone, Metabolic syndrome, Insulin resistance, Inflammation marker

This is an Open Access article distributed under the terms of the Creative Commons Attribution Non-Commercial License (http://creativecommons.org/licenses/by-nc/4.0) which permits unrestricted non-commercial use, distribution, and reproduction in any medium, provided the original work is properly cited.

Copyright (C 2015 The Korean Society for Clinical Laboratory Science. All rights reserved.
Corresponding author: Kyung-A Shin Department of Clinical Laboratory Science, Shinsung University, Dangjin 31801 Tel: 82-41-350-1408 E-mail:mobitz2@daum.net

Received: September 1, 2015 Revised: $1^{\text {st: }}$ October 13, 2015 Revised $2^{\text {nd }}$ : October 19, 2015 Revised $3^{\text {rd: }}$ : October 21, 2015 Accepted: October 22, 2015

\section{서 론}

대사증후군은 고혈압, 당뇨, 이상지질혈증, 복부비만 등 심혈관 질환 위험요인이 동시에 한 개체에서 발생하는 질환군으로, 당뇨병 과 심혈관계 죽상경화증의 위험을 증가시킨다(Miranda 등, 2005). 신체 에너지 대사조절은 각종 호르몬의 상호작용으로 이루어지며,
그 중 인슐린과 인슐린 저항성은 대사증후군 발병의 주된 병리기전 으로 알려져 있다(Hamburg 등, 2008). 갑상샘 호르몬 또한 교감신 경계와의 상호작용으로 에너지 대사조절 및 항상성 유지에 중요한 역할을 하며, 대사증후군과 갑상샘기능장애는 이환율 및 사망률의 위험 증가와 관련이 있는 내분비 질환이다(Silva, 1995; Iwen 등, 2013). 
갑상샘기능이상은 체중변화를 동반하며, 심혈관질환 및 대사적 합병증과 관련이 있다(Di Bello 등, 2007; Portella 등, 2007). 갑상 샘기능 중 갑상샘자극호르몬(thyroid-stimulating hormone, TSH)은 유리티록신(free thyroxine, FT4)과 역log/선형관계를 나 타내며, FT4는 혈중 지질 및 당대사에 중요한 역할을 한다(Andersen 등, 2002; Duntas, 2002; Fommei와 Iervasi, 2002).

갑상샘기능과 혈청지질과의 관련성에 대한 연구에서 $\mathrm{TSH}$ 는 대 사증후군 위험요인 중 고중성지방혈증과 양의 상관관계를 보인 반 면, FT4는 비만 및 고중성지방혈증과 음의 상관관계를 보였다 (Nah와 Lee, 2009). 한편, 갑상샘기능저하증은 총 콜레스테롤과 $\mathrm{LDL}$-콜레스테롤(low density lipoprotein)을 증가시켜 심혈관질 환과 동맥경화의 위험을 증가시키는 것으로 보고된다(Jung 등, 2002). American Health Aging and Body Composition (Health $\mathrm{ABC}$ )연구에 따르면 혈압, HDL-콜레스테롤(high density lipoprotein), 중성지방, 공복혈당이 갑상샘기능장애에 영향을 미치며, 갑상샘기능항진증 뿐만 아니라 갑상샘기능저하증에서도 인슐린 저항성을 포함한 대사증후군의 결과로 나타나는 기능상의 변화가 유발된다(Waring 등, 2012). 이와 같은 갑상샘기능이상과 대사증 후군은 증상의 유사성 때문에 갑상샘이상의 결과로 대사증후군이 발생한다는 연구가 보고되고 있다(Waring 등, 2012; Pangaluri 등, 2013). 그러나 갑상샘 호르몬은 성별에 따라 차이를 보이며, 성 호르몬이 갑상샘 호르몬에 영향을 미치는 것으로 알려져 있다(da Costa 등, 2001). 대사증후군 또한 성별에 따라 발현 양상에 차이를 보이고 있으나 선행 연구들은 대부분 여성과 갑상샘기능이상인 대 상자를 중심으로 연구가 이루어졌으며, 인슐린 저항성과 같은 대사 증후군 위험요인을 광범위하게 포함하고 있지 못하다(Jung 등, 2002; Kragelund 등, 2007; Roos 등, 2007).

이에 본 연구에서는 갑상샘기능이상을 동반하지 않은 성인 남성 을 대상으로 갑상샘 호르몬과 대사증후군 위험요인과의 연관성을 밝히고, 갑상샘 호르몬이 대사증후군에 미치는 영향을 조사하고자 하였다.

\section{재료 및 방법}

\section{1. 연구 대상}

경기지역 일개 종합병원에서 2011년 1월부터 2013년 12월까 지 건강검진센터에서 갑상샘 기능검사를 실시한 20세 이상 80세 이하의 성인 남성 12,250 명을 대상으로 하였다. 갑상샘 호르몬 치 료제를 복용하는 자, 갑상샘종이 있거나 갑상샘 질환의 병력이 있 는 자는 연구에서 제외하였다. 현재와 과거병력에 대해서는 설문지 를 통해 수집하였으며, 이 중 대사증후군 진단군은 1,461 명이었고
정상군은 10,789 명이었다. 갑상샘기능은 FT 4 와 TSH 농도를 측정 하여 평가하였다. 본 연구는 경기도 분당제생병원 임상연구심의위 원회의 심의와 승인을 받은 후 시행하였다.

\section{2. 연구 변수}

\section{1) 신체 계측 및 혈압 측정}

체중은 Autobody Weight (YK-150N, Korea)로, 신장은 STDK-AD (Shintokyo Desshikizai Co., Japan)로 측정하였다. 또한 체질량지수(body mass index, BMI)는 체중 $(\mathrm{kg})$ 을 신장 $(\mathrm{m})^{2}$ 로 나 눈 값으로 계산하였다. 허리둘레는 양발을 $25 \sim 30 \mathrm{~cm}$ 간격으로 벌 리고 숨을 내쉰 상태에서 늑골 하단과 장골능선 상단 부위의 교차 점의 중간부위를 측정하였다. 혈압은 앉은 자세에서 10 분간 안정 을 취한 후 수은 혈압계를 이용하여 수축기와 이완기 혈압을 측정 하였다.

\section{2) 혈액분석}

혈액검사는 8시간 이상 금식 후 오전 8시에 채혈을 실시하였다. 혈액분석은 총콜레스테롤, 중성지방, $\mathrm{HDL}$-콜레스테롤, $\mathrm{LDL}-$ 콜 레스테롤(low density lipoprotein), 공복혈당, 고감도 C-반응성 단백질(high sensitivity C-reactive protein, hs-CRP), 요산을 TBA-200FR NEO (Toshiba, Japan)로 측정하였다. 당화혈색소 (hemoglobin A1c, HbA1c)는 고성능액체크로마토그래피(high performance liquid chromatography, HPLC) 원리를 이용하여 Variant II (Bio Rad, U.S.A)로 측정하였다. 또한 인슐린, FT4, TSH 는 Modular Analytics E170 (Roche, Switzerland) 장비를 이용하 여 전기화학발광면역분석법(electrochemiluminescence immunoassay, ECLIA)의 원리로 검사하였다. 인슐린 저항성을 나타내는 HOMA-IR (homeostasis model assessment of insulin resistance) 는 [fasting insulin $(\mathrm{uU} / \mathrm{ml}) \times$ fasting glucose $(\mathrm{mg} / \mathrm{dL}) / 405$ ] 공식 을 이용하여 계산하였다.

\section{3) 대사증후군 진단기준}

대사증후군 판정기준은 AHA/NHLBI (American Heart Association/National Heart, Lung, and Blood Institute)의 기준에 따 라 1) 혈압 $130 / 85 \mathrm{mmHg}$ 이상 또는 약물치료 하는 경우 2) 공복혈당 $100 \mathrm{mg} / \mathrm{dL}$ 이상 또는 약물치료 하는 경우 3) 중성지방이 $150 \mathrm{mg} / \mathrm{dL}$ 이상 또는 고중성지방혈증 약물치료 중인 대상자 4) HDL-콜레스테 롤 남성 $40 \mathrm{mg} / \mathrm{dL}$ 미만인 경우 5) 허리둘레는 대한비만학회 기준에 따라 기준에 따라 남성 $90 \mathrm{~cm}$ 이상인 경우를 대사증후군 진단기준으 로 설정하였으며, 제시한 5 가지 항목 중 3 가지 이상 해당하는 경우 대 사증후군 진단군으로 분류하였다(Grundy 등, 2005; Oh, 2011). 


\section{3. 통계 분석}

본 연구의 기술 통계치는 평균과 표준편차로 제시하였다. 대사 증후군 진단유무에 따른 대상자의 의학적 특징과 대사증후군 위험 요인의 수준에 따른 갑상선 호르몬의 차이를 알아보기 위해 독립표 본 $t$ 검정을 실시하였다. TSH와 FT4의 사분위수에 따른 인체측정 변인과 생화학적 지표의 차이를 비교하기 위해 일원변량분석 (one-way ANOVA)을 실시하였다. 일원변량분석을 실시한 결과 통계적으로 유의한 차이가 있는 경우 사후분석으로 bonferroni를 시행하였다. 또한 대사증후군 위험요인과 갑상선 호르몬과의 관계 를 알아보기 위해 다중선형회귀분석을 실시하였으며, 대사증후군 발생위험을 알아보기 위해로지스틱회귀분석을 시행하였다. 통계 분석은 SPSS 21.0 window version (SPSS Inc., Chicago, IL, U.S.A)을 사용하였으며, 통계적 유의수준은 $p<0.05$ 로 설정하였다.

\section{결 과}

\section{1. 대사증후군 진단 유무에 따른 대상자의 의학적 특징}

대사증후군 진단 유무에 따른 연령, 체중, BMI, 허리둘레, 수축 기와 이완기 혈압, 총콜레스테롤, 중성지방, 공복혈당, $\mathrm{HbA1c}$, 인 슐린, HOMA-IR, hs-CRP, 요산은 정상군보다 대사증후군 진단군 에서 높았다(각각 $p<0.001$ ). 그러나 HDL-콜레스테롤과 FT4는 정상군보다 대사증후군 진단군에서 낮았으며(각각 $p<0.001$ ), 신 장, LDL-콜레스테롤, TSH는 집단간 차이가 없었다(Table 1).

\section{TSH 사분위수에 따른 인체측정 변인 및 생화학적 요인의 차이}

$\mathrm{TSH}$ 의 사분위수에 따른 집단간 차이를 본 결과, 체중은 1 사분위 수와 2 사분위수보다 3 사분위수와 4 사분위수에서 높았다 $(p=0.007)$. 수축기와 이완기 혈압은 1 사분위수보다 2 사분위수와 4 사분위수 에서 높았다(각각 $p=0.006, p=0.001$ ). 총콜레스테롤과 $\mathrm{hs}-\mathrm{CRP}$ 는 1 사분위수보다 2 사분위수, 3 사분위수, 4 사분위수가 높았다(각각 $p<0.001)$. 중성지방과 요산은 1 사분위수와 2 사분위수보다 3 사분 위수와 4 사분위수가 높았으며, 4 사분위수는 2 사분위수보다 높았 다(각각 $p<0.001)$ LDL-콜레스테롤은 1 사분위수보다 4 사분위수 에서 높았다 $(p=0.013)$. 또한 공복혈당은 4 사분위수는 1 사분위수 와 2 사분위수보다 높았으며, 3 사분위수는 2 사분위수보다 높았다 $(p=0.001)$. TSH는 가장 낮은 1 사분위수에서 가장 높은 4 사분위수 로 진행할수록 높아졌으며, FT4는 가장 낮은 1 사분위수에서 가장 높은 4사분위수로 진행할수록 낮아졌다(각각 $p<0.001)$. 그러나 연령, 신장, $\mathrm{BMI}$, 허리둘레, $\mathrm{HDL}$-콜레스테롤, $\mathrm{HbA1c}$, 인슐린, HOMA-IR은 집단간 차이가 없었다(Table 2).
Table 1. Anthropometric and biochemical parameters of study subjects according to presence of metabolic syndrome

\begin{tabular}{|c|c|c|c|}
\hline \multirow{2}{*}{ Variables } & \multicolumn{3}{|c|}{ Male $(n=12,250)$} \\
\hline & MS $(n=1,461)$ & No MS $(10,789)$ & $p^{\star}$ \\
\hline Age, y & $49.34 \pm 10.80$ & $45.79 \pm 10.91$ & $<0.001$ \\
\hline Height, cm & $171.45 \pm 6.40$ & $171.35 \pm 6.35$ & 0.589 \\
\hline Weight, kg & $81.26 \pm 10.86$ & $71.35 \pm 9.56$ & $<0.001$ \\
\hline $\mathrm{BMI}, \mathrm{kg} / \mathrm{m}^{2}$ & $27.58 \pm 2.84$ & $24.27 \pm 2.72$ & $<0.001$ \\
\hline WC, $\mathrm{cm}$ & $92.19 \pm 6.63$ & $82.66 \pm 7.01$ & $<0.001$ \\
\hline $\mathrm{SBP}, \mathrm{mmHg}$ & $123.72 \pm 14.93$ & $111.30 \pm 12.16$ & $<0.001$ \\
\hline DBP, $\mathrm{mmHg}$ & $80.30 \pm 10.64$ & $71.96 \pm 9.36$ & $<0.001$ \\
\hline $\mathrm{TC}, \mathrm{mg} / \mathrm{dL}$ & $199.67 \pm 36.54$ & $194.59 \pm 33.55$ & $<0.001$ \\
\hline $\mathrm{TG}, \mathrm{mg} / \mathrm{dL}$ & $240.03 \pm 112.66$ & $131.50 \pm 80.34$ & $<0.001$ \\
\hline $\mathrm{HDL}-\mathrm{C}, \mathrm{mg} / \mathrm{dL}$ & $43.73 \pm 10.28$ & $53.04 \pm 11.65$ & $<0.001$ \\
\hline $\mathrm{LDL}-\mathrm{C}, \mathrm{mg} / \mathrm{dL}$ & $123.08 \pm 33.04$ & $121.82 \pm 30.22$ & 0.176 \\
\hline $\mathrm{FBS}, \mathrm{mg} / \mathrm{dL}$ & $110.24 \pm 30.76$ & $90.44 \pm 17.30$ & $<0.001$ \\
\hline $\mathrm{HbA} 1 \mathrm{c}, \%$ & $6.24 \pm 1.14$ & $5.58 \pm 0.65$ & $<0.001$ \\
\hline Insulin, uU/mL & $7.80 \pm 3.96$ & $4.82 \pm 2.92$ & $<0.001$ \\
\hline HOMA-IR & $2.15 \pm 1.32$ & $1.11 \pm 0.75$ & $<0.001$ \\
\hline hs-CRP, mg/dL & $0.22 \pm 0.51$ & $0.17 \pm 0.47$ & $<0.001$ \\
\hline Uric acid, $\mathrm{mg} / \mathrm{dL}$ & $6.30 \pm 1.42$ & $5.99 \pm 1.25$ & $<0.001$ \\
\hline $\mathrm{TSH}, \mu \mathrm{IU} / \mathrm{mL}$ & $2.21 \pm 2.09$ & $2.19 \pm 3.12$ & 0.810 \\
\hline FT4, ng/dL & $1.31 \pm 0.20$ & $1.34 \pm 0.28$ & $<0.001$ \\
\hline
\end{tabular}

Abbreviation: MS, metabolic syndrome; BMI, body mass index; WC, waist circumference; SBP, systolic blood pressure; DBP, diastolic blood pressure; TC, total cholesterol; TG, triglyceride; $\mathrm{HDL}-\mathrm{C}$, high density lipoprotein cholesterol; LDL-C, low density lipoprotein cholesterol; FBS, fasting blood sugar; $\mathrm{HbA} 1 \mathrm{c}$, hemoglobin A1c; HOMA-IR, homeostasis model assessment of insulin resistance; hs-CRP, high sensitivity C-reactive protein; TSH, thyroid stimulating hormone; FT4, free thyroxine.

Values are presented as mean $\pm S D$.

${ }^{*}$ Calculated by independent samples $t$-test.

\section{FT4 사분위수에 따른 인체측정 변인 및 생화학적 요인의 차이}

$\mathrm{FT} 4$ 를 사분위수로 나누어 집단간 차이를 본 결과, 연령은 1 사분 위수에서 4사분위수로 진행할수록 낮아졌으며, 신장과 FT4는 가 장 낮은 사분위수에서 가장 높은 사분위수로 진행할수록 높아졌다 (각각 $p<0.001$ ). BMI와 허리둘레는 1 사분위수와 2 사분위수보다 3 사분위수와 4 사분위수가 낮았으며, 4 사분위수는 2 사분위수와 3 사분위수보다 낮았다(각각 $p<0.001$. 수축기와 이완기 혈압 및 중 성지방은 1 사분위수보다 2 사분위수, 3 사분위수, 4 사분위수에서 낮았으며, 중성지방의 4 사분위수는 2 사분위수와 3 사분위수보다 낮았다(각각 $p<0.001$ ). HDL-콜레스테롤은 4 사분위수가 1 사분 위수, 2 사분위수, 3 사분위수보다 높았다 $(p<0.001)$. 공복혈당, 인 슐린, HOMA-IR은 1 사분위수와 2 사분위수보다 3 사분위수와 4 사 분위수가 낮았으며, 4 사분위수는 2 사분위수보다 낮았다(각각 $p<0.001$ ). 또한 $\mathrm{HbA} 1 \mathrm{c}$ 는 1 사분위수보다 2 사분위수, 3 사분위수, 4 사분위수가 낮았으며, 4 사분위수는 2 사분위수보다 낮았다 $(p$ <0.001). hs-CRP는 1 사분위수보다 3 사분위수와 4 사분위수가 낮 
Table 2. Comparison of anthropometric and biochemical parameters of subjects according to TSH quartile

\begin{tabular}{|c|c|c|c|c|c|}
\hline Variables & $\begin{array}{c}1^{\text {st }} \text { quartile } \\
(\leq 1.25, n=3,319)\end{array}$ & $\begin{array}{c}2^{\text {nd }} \text { quartile } \\
(1.26 \sim 1.86, n=3,172)\end{array}$ & $\begin{array}{c}3^{\text {rd }} \text { quartile } \\
(1.87 \sim 2.73, n=3,036)\end{array}$ & $\begin{array}{c}4^{\text {th }} \text { quartile } \\
(\geq 2.74, \quad n=2,723)\end{array}$ & $p^{*}$ \\
\hline Age, y & $46.48 \pm 10.97$ & $45.95 \pm 10.74$ & $45.90 \pm 10.99$ & $46.52 \pm 11.15$ & 0.057 \\
\hline Height, cm & $171.13 \pm 6.35$ & $171.53 \pm 6.37$ & $171.42 \pm 6.33$ & $171.39 \pm 6.35$ & 0.071 \\
\hline Weight, kg & $72.02 \pm 10.12$ & $72.60 \pm 10.28$ & $72.76 \pm 10.26^{\dagger}$ & $72.83 \pm 10.30^{\dagger}$ & 0.007 \\
\hline $\mathrm{BMI}, \mathrm{kg} / \mathrm{m}^{2}$ & $24.56 \pm 2.91$ & $24.63 \pm 2.94$ & $24.73 \pm 2.95$ & $24.75 \pm 2.94$ & 0.052 \\
\hline WC, $\mathrm{cm}$ & $83.52 \pm 7.63$ & $83.73 \pm 7.69$ & $83.96 \pm 7.51$ & $84.03 \pm 7.63$ & 0.051 \\
\hline SBP, $\mathrm{mmHg}$ & $112.13 \pm 12.50$ & $113.15 \pm 12.96^{\dagger}$ & $112.79 \pm 13.42$ & $113.13 \pm 13.82^{\dagger}$ & 0.006 \\
\hline $\mathrm{DBP}, \mathrm{mmHg}$ & $72.43 \pm 9.66$ & $73.32 \pm 9.64^{\dagger}$ & $72.88 \pm 10.06$ & $73.24 \pm 10.27^{\dagger}$ & 0.001 \\
\hline $\mathrm{TC}, \mathrm{mg} / \mathrm{dL}$ & $193.13 \pm 33.78$ & $195.48 \pm 32.77^{\dagger}$ & $195.97 \pm 35.01^{\dagger}$ & $196.54 \pm 34.24^{\dagger}$ & $<0.001$ \\
\hline $\mathrm{TG}, \mathrm{mg} / \mathrm{dL}$ & $138.21 \pm 88.92$ & $143.03 \pm 87.86$ & $148.15 \pm 95.98^{\dagger}$ & $149.56 \pm 94.66^{\dagger}$ & $<0.001$ \\
\hline $\mathrm{HDL}-\mathrm{C}, \mathrm{mg} / \mathrm{dL}$ & $52.10 \pm 11.94$ & $52.06 \pm 11.81$ & $51.75 \pm 11.93$ & $51.78 \pm 11.87$ & 0.540 \\
\hline $\mathrm{LDL}-\mathrm{C}, \mathrm{mg} / \mathrm{dL}$ & $120.58 \pm 30.81$ & $122.15 \pm 29.77$ & $122.28 \pm 31.04$ & $123.12 \pm 30.61^{\dagger}$ & 0.013 \\
\hline $\mathrm{FBS}, \mathrm{mg} / \mathrm{dL}$ & $93.38 \pm 20.56$ & $93.57 \pm 21.53$ & $92.14 \pm 19.68^{\dagger}$ & $91.92 \pm 19.75^{\dagger, \ddagger}$ & 0.001 \\
\hline $\mathrm{HbA} 1 \mathrm{c}, \%$ & $5.68 \pm 0.75$ & $5.68 \pm 0.82$ & $5.64 \pm 0.74$ & $5.63 \pm 0.70$ & 0.051 \\
\hline Insulin, $\mathrm{uU} / \mathrm{mL}$ & $5.12 \pm 3.36$ & $5.30 \pm 3.09$ & $5.23 \pm 3.03$ & $5.21 \pm 3.47$ & 0.844 \\
\hline HOMA-IR & $1.23 \pm 0.94$ & $1.30 \pm 0.97$ & $1.23 \pm 0.82$ & $1.24 \pm 0.95$ & 0.519 \\
\hline $\mathrm{hs}-\mathrm{CRP}, \mathrm{mg} / \mathrm{dL}$ & $0.20 \pm 0.66$ & $0.17 \pm 0.38^{\dagger}$ & $0.16 \pm 0.36^{\dagger}$ & $0.16 \pm 0.41^{\dagger}$ & $<0.001$ \\
\hline Uric acid, mg/dL & $5.94 \pm 1.28$ & $6.00 \pm 1.25$ & $6.05 \pm 1.27^{\dagger}$ & $6.12 \pm 1.30^{\dagger, \ddagger}$ & $<0.001$ \\
\hline $\mathrm{TSH}, \mu \mathrm{IU} / \mathrm{mL}$ & $0.87 \pm 0.29$ & $1.55 \pm 0.17^{\dagger}$ & $2.25 \pm 0.24^{\dagger, \neq}$ & $4.50 \pm 5.73^{\dagger, \neq, \S}$ & $<0.001$ \\
\hline FT4, ng/dL & $1.38 \pm 0.46$ & $1.34 \pm 0.15^{\dagger}$ & $1.32 \pm 0.15^{\dagger, \ddagger}$ & $1.29 \pm 0.17^{\dagger, \uparrow, 8}$ & $<0.001$ \\
\hline
\end{tabular}

Abbreviation: BMI, body mass index; WC, waist circumference; SBP, systolic blood pressure; DBP, diastolic blood pressure; TC, total cholesterol; TG, triglyceride; HDL-C, high density lipoprotein cholesterol; LDL-C, low density lipoprotein cholesterol; FBS, fasting blood sugar; HbA1c, hemoglobin A1c; HOMA-IR, homeostasis model assessment of insulin resistance; hs-CRP, high sensitivity C-reactive protein; TSH, thyroid stimulating hormone; FT4, free thyroxine.

Values are presented as mean \pm SD.

${ }^{*}$ Calculated by ANOVA and bonferroni test. ${ }^{\dagger}$ Significantly different from $1^{\text {st }}$ quartile. ${ }^{\dagger}$ Significantly different from $2^{\text {nd }}$ quartile. ${ }^{\S}$ Significantly different from $3^{\text {rd }}$ quartile.

았으며, 4 사분위수는 2 사분위수와 3 사분위수보다 낮았다 $p<0.001)$. 요산은 1 사분위수보다 2 사분위수, 3 사분위수, 4 사분위수에서 높 았다( $p=0.002)$. TSH는 1 사분위수보다 2 사분위수, 3 사분위수, 4 사분위수에서 낮았으며, 4 사분위수는 1 사분위수보다 낮았다 $(p$ $<0.001)$. 그러나 체중, 총콜레스테롤, LDL-콜레스테롤은 집단간 차이가 없었다(Table 3).

\section{4. 대사증후군 위험요인 수준에 따른 갑상샘기능의 차이}

정상군보다 복부비만과 높은 혈압의 경우 FT4가 낮았으며(각각 $p=0.001, p=0.005)$, 고중성지방혈증과 높은 혈당의 경우도 정상 군보다 FT 4 가 낮았다(각각 $p<0.001, p=0.005$ ). 그러나 저 HDL콜레스테롤혈증은 집단간 갑상샘기능에 차이가 없었다. TSH는 고 중성지방혈증에서 정상군보다 높았으며 $(p=0.047)$, 복부비만, 높 은 혈압, 저 $\mathrm{HDL}$-콜레스테롤혈증, 높은 혈당은 정상군과 비교해 TSH에 차이가 없었다(Table 4).

\section{5. 갑상선 호르몬과 대사증후군 위험요인간의 관련성}

$\mathrm{TSH}$ 는 대사증후군 위험요인에 영향을 미치지 않는 것으로 나타 났으나, FT4는 대사증후군 위험요인 중 허리둘레, 중성지방에 영 향을 미치는 것으로 나타났다(각각 $p<0.001$ ) (Table 5). FT4를 사
분위수로 나눈 후, 각 사분위 범위에서 대사증후군 발생을 비교한 결과 1 사분위수를 기준으로 4 사분위수(OR: $0.779,95 \% \mathrm{CI}: 0.683$ 0.889)의 대사증후군 발생위험도가 1 사분위수(OR: $0.893,95 \%$ CI: 0.787 1.014)보다 0.77배 낮게 나타났다(Table 6).

\section{고 찰}

대사증후군은 심혈관질환의 위험인자인 고혈압, 당뇨, 이상지 질혈증, 복부비만 등이 한 개체에서 동반되는 질환군으로, 당뇨병 과 심혈관계 죽상 동맥경화증의 위험을 증가시킨다(Miranda 등, 2005). 대사증후군과 갑상샘기능장애는 동시에 발생하는 경우가 있으며, 대사증후군을 가진 대상자에게서 갑상샘질환의 유병률이 높은 것으로 보고된다(Agarwal 등, 2011).

갑상샘기능이 정상인 성인에서 갑상샘 호르몬은 인슐린 저항성 과는 독립적으로 대사증후군 위험요인과 관련이 있으며, 갑상샘기 능저하증에서 혈압의 상승과 총콜레스테롤 및 LDL-콜레스테롤, 중성지방의 증가와 같은 지질변화가 나타난다(Jung 등, 2002; Roos 등, 2007). 이와 같이 갑상샘기능저하증에서 혈중지질의 상 승은 갑상샘 호르몬이 심혈관질환 및 대사증후군 위험요인으로 작 용할 가능성이 있음을 시사한다. 
Table 3. Comparison of anthropometric and biochemical parameters of subjects according to FT4 quartile

\begin{tabular}{|c|c|c|c|c|c|}
\hline Variables & $\begin{array}{c}1^{\text {st }} \text { quartile } \\
(\leq 1.16, n=1,949)\end{array}$ & $\begin{array}{c}2^{\text {nd }} \text { quartile } \\
(1.17 \sim 1.28, n=2,957)\end{array}$ & $\begin{array}{c}3^{\text {rd }} \text { quartile } \\
(1.29 \sim 1.40, n=3,399)\end{array}$ & $\begin{array}{c}4^{\text {th }} \text { quartile } \\
(\geq 1.41, n=3,944)\end{array}$ & $p^{\star}$ \\
\hline Age, y & $51.20 \pm 11.30$ & $47.51 \pm 11.20^{\dagger}$ & $45.27 \pm 10.53^{\dagger, \neq}$ & $43.59 \pm 9.96^{\dagger, \ddagger, \S}$ & $<0.001$ \\
\hline Height, cm & $169.89 \pm 6.32$ & $171.13 \pm 6.38^{\dagger}$ & $171.63 \pm 6.27^{\dagger, \ddagger}$ & $172.03 \pm 6.29^{\dagger, \uparrow, 8}$ & $<0.001$ \\
\hline Weight, kg & $72.30 \pm 10.14$ & $72.77 \pm 10.23$ & $72.86 \pm 10.33$ & $72.20 \pm 10.20$ & 0.056 \\
\hline $\mathrm{BMI}, \mathrm{kg} / \mathrm{m}^{2}$ & $25.01 \pm 2.93$ & $24.81 \pm 2.91$ & $24.69 \pm 2.88^{\dagger}$ & $24.37 \pm 2.98^{\dagger, \neq, \S}$ & $<0.001$ \\
\hline WC, $\mathrm{cm}$ & $84.59 \pm 7.57$ & $84.08 \pm 7.64$ & $83.89 \pm 7.51^{\dagger}$ & $83.11 \pm 7.66^{\dagger, \ddagger, \S}$ & $<0.001$ \\
\hline $\mathrm{SBP}, \mathrm{mmHg}$ & $114.60 \pm 14.02$ & $112.85 \pm 13.41^{\dagger}$ & $112.49 \pm 12.99^{\dagger}$ & $112.08 \pm 12.56^{\dagger}$ & $<0.001$ \\
\hline $\mathrm{DBP}, \mathrm{mmHg}$ & $73.95 \pm 10.08$ & $73.02 \pm 10.14^{\dagger}$ & $72.80 \pm 9.78^{\dagger}$ & $72.54 \pm 9.70^{+}$ & $<0.001$ \\
\hline $\mathrm{TC}, \mathrm{mg} / \mathrm{dL}$ & $195.53 \pm 34.97$ & $195.38 \pm 34.41$ & $195.64 \pm 33.67$ & $194.53 \pm 33.35$ & 0.500 \\
\hline $\mathrm{TG}, \mathrm{mg} / \mathrm{dL}$ & $159.18 \pm 108.01$ & $147.87 \pm 90.34^{\dagger}$ & $144.05 \pm 89.34^{\dagger}$ & $134.97 \pm 85.06^{\dagger, \uparrow, \S}$ & $<0.001$ \\
\hline $\mathrm{HDL}-\mathrm{C}, \mathrm{mg} / \mathrm{dL}$ & $50.94 \pm 12.10$ & $51.69 \pm 11.73$ & $51.79 \pm 11.83$ & $52.73 \pm 11.90^{\dagger, \uparrow, \S}$ & $<0.001$ \\
\hline $\mathrm{LDL}-\mathrm{C}, \mathrm{mg} / \mathrm{dL}$ & $120.83 \pm 31.42$ & $122.10 \pm 30.76$ & $122.67 \pm 30.05$ & $121.86 \pm 30.43$ & 0.218 \\
\hline $\mathrm{FBS}, \mathrm{mg} / \mathrm{dL}$ & $94.85 \pm 21.14$ & $93.53 \pm 20.29$ & $92.32 \pm 20.03^{\dagger}$ & $91.66 \pm 20.46^{\dagger, \ddagger}$ & $<0.001$ \\
\hline $\mathrm{HbA} 1 \mathrm{c}, \%$ & $5.76 \pm 0.78$ & $5.67 \pm 0.72^{\dagger}$ & $5.65 \pm 0.75^{\dagger}$ & $5.61 \pm 0.78^{\dagger, \neq}$ & $<0.001$ \\
\hline Insulin, $\mathrm{uU} / \mathrm{mL}$ & $5.89 \pm 3.60$ & $5.59 \pm 3.62$ & $5.12 \pm 2.92^{\dagger}$ & $4.69 \pm 2.93^{\dagger, \ddagger}$ & $<0.001$ \\
\hline HOMA-IR & $1.43 \pm 1.06$ & $1.36 \pm 1.05$ & $1.21 \pm 0.79^{\dagger, \ddagger}$ & $1.12 \pm 0.81^{\dagger, \ddagger}$ & $<0.001$ \\
\hline $\mathrm{hs}-\mathrm{CRP}, \mathrm{mg} / \mathrm{dL}$ & $0.22 \pm 0.53$ & $0.19 \pm 0.59$ & $0.18 \pm 0.51^{\dagger}$ & $0.14 \pm 0.28^{\dagger, \uparrow, \S}$ & $<0.001$ \\
\hline Uric acid, mg/dL & $5.93 \pm 1.29$ & $6.03 \pm 1.27^{\dagger}$ & $6.06 \pm 1.28^{\dagger}$ & $6.03 \pm 1.27^{\dagger}$ & 0.002 \\
\hline $\mathrm{TSH}, \mu \mathrm{IU} / \mathrm{mL}$ & $3.09 \pm 6.78$ & $2.20 \pm 1.73^{\dagger}$ & $2.04 \pm 1.23^{\dagger}$ & $1.88 \pm 1.21^{\dagger, \uparrow}$ & $<0.001$ \\
\hline $\mathrm{FT} 4, \mathrm{ng} / \mathrm{dL}$ & $1.08 \pm 0.07$ & $1.23 \pm 0.03^{\dagger}$ & $1.34 \pm 0.03^{\dagger, \neq}$ & $1.53 \pm 0.39^{\dagger, \neq, \S}$ & $<0.001$ \\
\hline
\end{tabular}

Abbreviation: BMI, body mass index; WC, waist circumference; SBP, systolic blood pressure; DBP, diastolic blood pressure; TC, total cholesterol; TG, triglyceride; HDL-C, high density lipoprotein cholesterol; LDL-C, low density lipoprotein cholesterol; FBS, fasting blood sugar; HbA1c, hemoglobin A1c; HOMA-IR, homeostasis model assessment of insulin resistance; hs-CRP, high sensitivity C-reactive protein; TSH, thyroid stimulating hormone; FT4, free thyroxine.

Values are presented as mean \pm SD.

${ }^{*}$ Calculated by ANOVA and bonferroni test, ${ }^{\dagger}$ Significantly different from $1^{\text {st }}$ quartile, ${ }^{\dagger}$ Significantly different from $2^{\text {nd }}$ quartile, ${ }^{\S}$ Significantly different from $3^{\text {rd }}$ quartile.

Table 4. TSH and FT4 levels according to the levels of each metabolic syndrome risk factors

\begin{tabular}{|c|c|c|c|c|}
\hline Variables & TSH & $p^{\star}$ & FT4 & $p^{\star}$ \\
\hline \multicolumn{5}{|l|}{ WC, cm } \\
\hline$\geq 90$ & $2.23 \pm 2.42$ & 0.464 & $1.32 \pm 0.18$ & 0.001 \\
\hline$<90$ & $2.18 \pm 3.16$ & & $1.34 \pm 0.30$ & \\
\hline \multicolumn{5}{|l|}{$\mathrm{BP}, \mathrm{mmHg}$} \\
\hline $\mathrm{SBP} \geq 130$ or $\mathrm{DBP} \geq 85$ & $2.27 \pm 2.08$ & 0.196 & $1.32 \pm 0.23$ & 0.005 \\
\hline SBP $<130$ or $\mathrm{DBP}<85$ & $2.18 \pm 3.18$ & & $1.34 \pm 0.28$ & \\
\hline \multicolumn{5}{|l|}{$\mathrm{HDL}-\mathrm{C}, \mathrm{mg} / \mathrm{dL}$} \\
\hline$<40$ & $2.17 \pm 1.70$ & 0.701 & $1.33 \pm 0.23$ & 0.175 \\
\hline$\geq 40$ & $2.20 \pm 3.17$ & & $1.34 \pm 0.28$ & \\
\hline \multicolumn{5}{|l|}{$\mathrm{TG}, \mathrm{mg} / \mathrm{dL}$} \\
\hline$\geq 150$ & $2.27 \pm 2.76$ & 0.047 & $1.31 \pm 0.17$ & $<0.001$ \\
\hline$<150$ & $2.15 \pm 3.15$ & & $1.35 \pm 0.32$ & \\
\hline \multicolumn{5}{|l|}{$\mathrm{FBS}, \mathrm{mg} / \mathrm{dL}$} \\
\hline$\geq 100$ & $2.12 \pm 2.24$ & 0.207 & $1.32 \pm 0.42$ & 0.005 \\
\hline$<100$ & $2.21 \pm 3.16$ & & $1.34 \pm 0.23$ & \\
\hline
\end{tabular}

Abbreviation: TSH, thyroid stimulating hormone; FT4, free thyroxine; WC, waist circumference; BP, blood pressure; HDL-C, high density lipoprotein cholesterol; TG, triglyceride; FBS, fasting blood sugar.

Values are presented as mean \pm SD.

${ }^{*}$ Calculated by independent samples $t$-test.

갑상선 호르몬은 세포의 에너지 조절 및 항상성에 필수적이며, 이러한작용은 말초 표적장기에 대한 중추신경계와갑상샘 호르몬 의 직접적인 상호작용을 통해 매개된다(Iwen 등, 2013). 갑상샘 기
능 중 FT4는 지질대사와 당대사에 중요한 역할을 하며, 특히 갑상 샘기능저하증에서 혈중 지질농도와 혈압에 영향을 미치는 것으로 알려져 있다(Duntas, 2002, Fommei와 Iervasi, 2002). TSH 농도 
Table 5. Association between thyroid functions and the components of the metabolic syndrome

\begin{tabular}{lrrrrrrrr}
\hline \multirow{2}{*}{ Variables } & \multicolumn{9}{c}{ TSH } & \multicolumn{3}{c}{ FT4 } \\
\cline { 2 - 9 } & B & SE & $\beta$ & $p^{\star}$ & B & SE & $\beta$ & $p^{\star}$ \\
\hline WC, cm & -0.008 & 0.023 & -0.003 & 0.715 & -1.092 & 0.249 & -0.040 & 0.001 \\
SBP, mmHg & 0.050 & 0.039 & 0.011 & 0.200 & -0.108 & 0.424 & -0.002 & 0.799 \\
DBP, mmHg & 0.041 & 0.030 & 0.012 & 0.168 & -0.420 & 0.323 & -0.012 & 0.193 \\
HDL-C, mg/dL & 0.050 & 0.036 & 0.013 & 0.167 & 0.510 & 0.391 & 0.012 & 0.192 \\
TG, mg/dL & 0.039 & 0.277 & 0.001 & 0.887 & -22.345 & 3.016 & -0.068 & $<0.001$ \\
FBS, mg/dL & -0.111 & 0.060 & -0.016 & 0.065 & -0.300 & 0.656 & -0.004 & 0.648 \\
\hline
\end{tabular}

Abbreviation: TSH, thyroid stimulating hormone; FT4, free thyroxine; WC, waist circumference; SBP, systolic blood pressure; DBP; diastolic blood pressure; TC, total cholesterol; HDL-C, high density lipoprotein cholesterol; TG, triglyceride; FBS, fasting blood sugar.

${ }^{*}$ Calculated by multiple linear regression analysis.

Table 6. Independent association between FT4 level and metabolic syndrome

\begin{tabular}{ccr}
\hline FT4 $(\mathrm{ng} / \mathrm{dL})$ & $\begin{array}{c}\text { OR }(95 \% \mathrm{Cl}) \text { for } \\
\text { metabolic syndrome }\end{array}$ & \multicolumn{1}{c}{$p^{\star}$} \\
\hline $1^{\text {st }}$ quartile & 1 & \\
$2^{\text {nd }}$ quartile & $0.893(0.787-1.014)$ & 0.082 \\
$3^{\text {th }}$ quartile & $0.841(0.738-0.959)$ & 0.009 \\
$4^{\text {th }}$ quartile & $0.779(0.683-0.889)$ & $<0.001$ \\
\hline
\end{tabular}

${ }^{*}$ Calculated by logistic regression analysis.

는 FT4와 역 $\log$ /선형관계를 보이며, 무증상 갑상샘기능이상을 보 이는 여성에서 TSH는 고중성지방혈증과 양의 상관관계가 있으며 FT4는 비만, 고혈당 및 고중성지방혈증과 음의 상관관계를 보였다 (Andersen 등, 2002; Nah와 Lee, 2009). 그러나 갑상샘 호르몬은 성별에 따라 차이를 보이며, 성 호르몬이 갑상샘 호르몬에 영향을 미치는 것으로 알려져 있으며(da Costa 등, 2001), 대사증후군 또 한 성별에 따라 발현 양상에 차이를 보인다. 그럼에도 불구하고 최 근의 선행연구들은 대부분 여성과 갑상샘기능이상인 대상자를 중 심으로 연구가 이루어졌다(Jung 등, 2002; Kragelund 등, 2007; Roos 등, 2007). 이에 본 연구에서는 정상 갑상샘 기능을 보이는 성 인 남성을 대상으로 갑상샘 호르몬과 대사증후군 위험요인과의 연 관성을 밝히고자 하였다.

본 연구결과 정상군보다 대사증후군 진단군에서 FT4가 낮았으 며, FT4는 대사증후군 위험요인 중 허리둘레, 중성지방에 영향을 미치는 것으로 나타났다. 또한 1 사분위수의 FT4를 기준으로 1 사분 위수보다 4사분위수에서 대사증후군 발생위험이 낮게 나타났다. 이상의 결과를 통해 갑상샘기능이상을 동반하지 않은 성인 남성에 서 TSH보다는 FT4가 대사증후군 발병과 관련이 있는 것으로 보인 다(Nah와 Lee, 2009). 한편, 대사증후군 위험요인 중 복부비만, 고 중성지방혈증, 혈압 및 혈당이 높은 경우 FT4가 낮았다. 또한 TSH 는 대사증후군 유무에 따른 차이는 없었으며, 대사증후군 위험요인 중 고중성지방혈증에서 $\mathrm{TSH}$ 농도가 높았다. 이러한 각각의 대사증 후군 위험요인의 유무에 따른 각 군에 대한 갑상샘 기능은 통계적
으로는 유의한 차이를 보였으나, 그 차이가 미비하여 생리적 기능 면에서 의미를 부여하기 어려워 추후 이와 관련된 전향적인 추가 연구가 필요할 것으로 생각된다.

갑상샘 호르몬은 지질 및 지단백의 합성과 분해에 영향을 미치 며, 지방분해를 촉진하는 카테콜아민의 지방조직에 대한 민감도 증 가로 내장비만을 감소시킨다(Walton 등, 1965; Krishna 등, 1968). 또한 갑상샘 호르몬은 혈관 평활근과 내피세포에 작용하여 혈관 저 항성을 감소시키지만, 갑상샘기능저하증에서는 혈관내피세포의 기능장애로 인해 죽상경화증과 심근경색증을 유발한다(Walton 등, 1965; Duntas 등, 2002; Fommei와 Iervasi, 2002).

인슐린 저항성은 대사증후군의 중요한 발병기전으로 받아들여 지고 있다(Miranda 등, 2005; Hamburg 등, 2008). 정상범위의 갑 상샘 호르몬 수치는 인슐린 감수성을 증가시키는 물질을 자극하지 만, 갑상샘기능항진증에서는 인슐린 저항성이 증가한다(Torrance 등, 1997; Wang 등, 2004).

본 연구결과 FT 4 의 가장 낮은 사분위수가 가장 높은 사분위수보 다 HbA1c, 인슐린, HOMA-IR가 높았으며, Roos 등(2007)은 낮은 FT4 분위수와 인슐린 저항성간에 연관성이 있다고 보고하였다. 또 한 여성을 대상으로 정상 FT4의 가장 낮은 사분위수에서 대사증후 군 발병 위험이 높게 나타났으며(Nah와 Lee, 2009), 본 연구결과 와 선행연구들의 결과를 통해 여성 뿐 아니라 남성에서도 갑상샘 호르몬을 대사증후군에 영향을 미치는 요인으로 간주하여 관심을 가져야할 것으로 생각된다.

$\mathrm{CRP}$ (C-reactive protein, $\mathrm{CRP}$ )는 간에서 생성되는 급성 반응 물질로써 전신성 염증상태를 평가하는 지표이며, 염증성 질환 이외 에 세포손상과 감염상태를 반영한다(Ridker 등, 2001). hs-CRP는 예민도와 정밀도가 높아 기존에 낮은 범위의 $\mathrm{CRP}$ 를 측정할 수 있 으며, 심혈관질환, 당뇨병, 대사증후군의 예측인자로 활용되고 있 다(Roberts 등, 2004). 본 연구에서는 FT4가 높은 분위수보다 낮은 분위수에서 hs-CRP 농도가 높았으나, 서 등(2003)의 연구에서는 갑상샘기능에 따른 $\mathrm{CRP}$ 농도는 차이가 없을 뿐 아니라 관련성도 
관찰되지 않았다. 그러나 고령여성에서 갑상샘 호르몬 수치가 높은 경우 관상동맥질환의 위험도가 높다고 보고되며, 이는 동맥경화반 (atherosclerotic plaque)에서 분비되는 염증성 사이토카인이 갑 상샘 호르몬에 영향을 미치기 때문이다(Hak 등, 2000; Papanicolaou, 2000). 이와 같은 결과는 갑상샘 호르몬과 염증지표인 hs-CRP간 의 관련성을 대변하는 결과이며, 선행연구와 일관되지 못한 결과를 보이는 것은 대상자의 성별과 연령대의 차이 때문인 것으로 생각된다. 결론적으로 정상 갑상샘 기능을 보이는 성인 남성에서 FT4는 정 상군보다 대사증후군 진단군에서 낮았으며, FT4가 낮은 분위수에 서 인슐린 저항성과 hs-CRP가 높았다. 또한 FT4는 허리둘레, 중성 지방에 영향을 미치는 것으로 나타났으며, FT4의 가장 높은 분위수 의 대사증후군 발생위험이 가장 낮은 분위수보다 낮게 나타났다. 본 연구의 제한점으로는 대규모 후향적 단면 조사연구로써 갑상샘 호르몬과 대사증후군 위험요인간의 관계에 대해 인과관계를 추론 하는데 어려움이 있다. 또한 경기지역 일개병원에서 건강검진을 받 은 성인 남성을 대상으로 하였으므로 일반적인 대사증후군 유병률 과는 차이가 있었을 것으로 예상된다. 더욱이 본 연구는 대사증후 군에 영향을 미치는 음주, 흡연, 운동 및 영양상태 등의 대사증후군 의 위험요인으로 간주되고 있는 변인에 대해 고려하지 못하였다.

\section{요 약}

갑상샘 호르몬은 교감신경계와의 상호작용으로 세포의 에너지 대사조절 및 항상성 유지에 중요한 역할을 한다. 본 연구는 건강검 진을 실시한 성인 남성을 대상으로 갑상샘 호르몬과 대사증후군 위 험요인간의 연관성을 밝히고자 하였다. 경기지역 일개 종합병원에 서 2011년 1월부터 2013년 12월까지 건강검진센터에서 종합건강 검진을 실시한 20 세 이상 80 세 이하의 남성 12,250 명을 대상으로 하였다. 대사증후군은 American Heart Association/National Heart, Lung, and Blood Institute (AHA/NHLBI, 2005)에서 제시 한 진단 기준에 따랐으며, 3 개 이상의 위험요인을 가진 경우 대사증 후군으로 진단하였다. 정상군보다 대사증후군 진단군에서 FT4가 낮았으며 $(p<0.001), \mathrm{TSH}$ 는 대사증후군 유무에 따른 차이는 없었 다. 또한 FT4는 대사증후군 위험요인 중 허리둘레, 중성지방에 영 향을 미치는 것으로 나타났으며(각각 $p<0.001$ ), FT4의 가장 낮은 사분위수가 가장 높은 사분위수보다 $\mathrm{HbA} 1 \mathrm{c}$, 인슐린, $\mathrm{HOMA}-\mathrm{IR}$, hs-CRP 농도가 높았다(각각 $p<0.001)$. FT4는 허리둘레, 중성지 방에 영향을 미치는 것으로 나타났으나, TSH는 대사증후군 위험요 인에 영향을 미치지 않는 것으로 나타났다. 또한 FT4의 가장 높은 분위수의 대사증후군 발생위험이 가장 낮은 분위수보다 낮게 나타 났다.

\author{
Acknowledgements: None \\ Funding: None \\ Conflict of interest: None
}

\section{References}

1. Agarwal G, Sudhakar MK, Mohini S, Senthil N, Amarabalan R. The prevalence of thyroid dysfunction among south Indian women with metabolic syndrome. JCDR. 2011, 5(2):152-154.

2. Andersen S, Pedersen KM, Bruun NH, Laurberg P. Narrow individual variations in serum $\mathrm{T}(4)$ and $\mathrm{T}(3)$ in normal subjects: a clue to the understanding of subclinical thyroid disease. J Clin Endocrinol Metab. 2002, 87(3):1068-1072.

3. da Costa VM, Moreira DG, Rosenthal D. Thyroid function and aging: gender-related differences. J Endocrinol. 2001, 171(1): 193-198.

4. Di Bello V, Aghini-Lombardi F, Monzani F, Talini E, Antonangeli L, Palagi C, et al. Early abnormalities of left ventricular myocardial characteristics associated with subclinical hyperthyroidism. J Endocrinol Invest. 2007, 30(7):564-571.

5. Duntas LH. Thyroid disease and lipids. Thyroid. 2002, 12(4): 287-293.

6. Duntas LH, Mantzou E, Koutras DA. Circulating levels of oxidized low-density lipoprotein in overt and mild hypothyroidism. Thyroid. 2002, 12(11):1003-1007.

7. Fommei E, Iervasi G. The role of thyroid hormone in blood pressure homeostasis: evidence from short-term hypothyroidism in humans. J Clin Endocrinol Metab. 2002, 87(5): 1996-2000.

8. Grundy SM, Cleeman JI, Daniels SR, Donato KA, Eckel RH, Franklin BA, et al. Diagnosis and management of the metabolic syndrome: an American Heart Association/National Heart, Lung, and Blood Institute Scientific Statement. Circulation. 2005, 112(17):2735-2752.

9. Hak AE, Pols HA, Visser TJ, Drexhage HA, Hofman A, Witteman JC. Subclinical hypothyroidism is an independent risk factor for atherosclerosis and myocardial infarction in elderly women: the Rotterdam Study. Ann Intern Med. 2000, 132(4):270-278.

10. Hamburg NM, Larson MG, Vita JA, Vasan RS, Keyes MJ, Widlansky ME, et al. Metabolic syndrome, insulin resistance, and brachial artery vasodilator function in Framingham Offspring participants without clinical evidence of cardiovascular disease. Am J Cardiol. 2008, 101(1):82-88.

11. Iwen KA, Schröder E, Brabant G. Thyroid hormones and the metabolic syndrome. Eur Thyroid J. 2013, 2(2):83-92.

12. Jung CH, Sung KC, Shin HS, Lhee HY, Park SH, Lee HC, et al. Thyroid dysfunction and their relation to cardiovascular risk factors such as lipid profile, hsCRP, waist hip ratio in Korea. Korean J Med. 2002, 63(3):273-282.

13. Kragelund C, Kø ber L, Faber J, Steffensen R, Hildebrandt P. Metabolic syndrome and mortality in stable coronary heart disease: relation to gender. Int J Cardiol. 2007, 121(1):62-67.

14. Krishna G, Hynie S, Brodie BB. Effects of thyroid hormones on adenyl cyclase in adipose tissue and on free fatty acid mobilization. Proc Natl Acad Sci. 1968, 59(3):884-889. 
15. Miranda PJ, DeFronzo RA, Califf RM, Guyton JR. Metabolic syndrome: definition, pathophysiology, and mechanisms. Am Heart J. 2005, 149(1):33-45.

16. Nah EH, Lee JG. The Relationship between Thyroid Function and the Risk Factors of Cardiovascular Disease at Female Medical Checkups. Korean J Lab Med. 2009, 29(4):286-292.

17. Oh SW. Obesity and Metabolic Syndrome in Korea. Diabetes Metab J. 2011, 35(6):561-566.

18. Pangaluri R, Akila S, Ebenezer W. Prevalence of metabolic syndrome and its components in women with subclinical hypothyroidism. Asian J Pharm Clin Res. 2013, 6(4):82-84.

19. Papanicolaou DA. Euthyroid Sick Syndrome and the role of cytokines. Rev Endocr Metab Disord. 2000, 1(1-2):43-48.

20. Portella RB, Pedrosa RC, Coeli CM, Buescu A, Vaisman M. Altered cardiovascular vagal responses in nonelderly female patients with subclinical hyperthyroidism and no apparent cardiovascular disease. Clin Endocrinol (Oxf). 2007, 67(2):290-294.

21. Ridker PM, Stampfer MJ, Rifai N. Novel risk factors for systemic atherosclerosis: a comparison of C-reactive protein, fibrinogen, homocysteine, lipoprotein(a), and standard cholesterol screening as predictors of peripheral arterial disease. JAMA. 2001, 285(19):2481-2485.

22. Roberts WL, CDC, AHA. CDC/AHA Workshop on Markers of Inflammation and Cardiovascular Disease: Application to Clinical and Public Health Practice: laboratory tests available to assess inflammation-performance and standardization: a background paper. Circulation. 2004, 110(25):572-576
23. Roos A, Bakker SJ, Links TP, Gans RO, Wolffenbuttel BH. Thyroid function is associated with components of the metabolic syndrome in euthyroid subjects. J Clin Endocrinol Metab. 2007, 92(2):491-496.

24. Silva JE. Thyroid hormone control of thermogenesis and energy balance. Thyroid. 1995, 5(6):481-492.

25. Suh JY, Lee WY, Park JS, Kim SW. Plasma CRP, apolipoprotein A-1, apolipoprotein B and Lp(a) according to thyroid function status. Korean J Med. 2003, 64(4):388-395.

26. Torrance CJ, Devente JE, Jones JP, Dohm GL. Effects of thyroid hormone on GLUT4 glucose transporter gene expression and NIDDM in rats. Endocrinology. 1997, 138(3):1204-1214.

27. Walton KW, Scott PJ, Dykes PW, Davies JW. The significance of alterations in serum lipids in thyroid dysfunction. II. Alterations of the metabolism and turnover of 131-I-low-density lipoproteins in hypothyroidism and thyrotoxicosis. Clin Sci. 1965, 29(2):217-238.

28. Wang H, Chu WS, Lu T, Hasstedt SJ, Kern PA, Elbein SC. Uncoupling protein-2 polymorphisms in type 2 diabetes, obesity, and insulin secretion. Am J Physiol Endocrinol Metab. 2004, 286(1):1-7.

29. Waring AC, Rodondi N, Harrison S, Kanaya AM, Simonsick EM, Miljkovic I, et al. Thyroid function and prevalent and incident metabolic syndrome in older adults: the Health, Ageing and Body Composition Study. Clin Endocrinol (Oxf). 2012, 76(6): 911-918. 